Vol. 3, Issue 2, pp. 1-16, 2021

Available online at: https://tljbm.org/jurnal/index.php/tljbm

\title{
The Role of Customer Satisfaction on the Relationship between Service Quality, Price and Word of Mouth (WOM): The Experience of EDTL.EP in Dili, Timor- Leste
}

\author{
Anderias Tani, Estanislau de Sousa Saldanha, Domingos M. B. Barreto \\ Graduate School-Master of Business Administration Program, Dili Institute of Technology, Timor-Leste \\ Email: ande.tani@gmail.com,estanislausaldanha@yahoo.com,domingosmb.barreto@gmail.com
}

\begin{abstract}
Service quality, price, customer satisfaction and word of mouth (WOM) appear to be the most important variables in today's business market, and many researchers have focused their attentions on their relationships. This research aims to test the influence of service quality and price to customer satisfaction and WOM, as well as the mediation effect of customer satisfaction in the relationship between service quality and price with WOM. Using accidental sample method, this study collects data from 315 respondents from Timor-Leste Electricity, State-owned Enterprise namely Eletricidade de Timor Leste, Empresa Publica (EDTL.EP) customers who are based in Dili Municipality, and tests hypothesis using SMART-PLS 3.0. Result shows that relationship between both service quality, price, customer satisfaction and WOM have positive and significant effect. This study contributes to the extensive discussions related to service quality, price, customer satisfaction and WOM in different industries. It is also expected to contribute to the improvement EDTL.EP management to provide better service quality and meet customers' expectation to encourage more positive recommendations to other customers via WOM.
\end{abstract}

Keywords: Service quality, Price, Satisfaction, Word of mouth (WOM)

\section{Introduction}

In the recent decades, more and more people starting to talk about the term of Word-of Mouth (WOM) as an important factor in the business market (Matzler, Teichmann, Strobl, \& Partel, 2019; Yasa \& Setiawan, 2018). Empirical studies show that buyers often have the tendency to listen to people they know and meet regularly because they are considered as independent and have no commercial interest with a company (Ng, David, \& Dagger, 2011; Nieto, Hernández-Maestro, \& Muñoz-Gallego, 2014; Rani \& Usman, 2019). Therefore, it gives more credibility to WOM as an essential variable in the market.

Customer satisfaction is an expression of happiness or unhappiness of a person after comparing expectation and perception about a product/ service (Kotler \& Keller, 2011). It is concerning the customers' feeling about the quality of a product/ service in accordance with their expectation (Parasuraman, Zeithaml, \& Berry, 1994; Rahman, Hassan, Osman-Gani, Fattah, \& Anwar, 2017). Price refers to the total amount of payment the buyer is willing to pay and the seller wants to accept in the market (Inoua \& Smith, 2020). When customers are satisfied with the quality of service according to the price they paid, the company is expected to retain more customers and therefore increasing its market share. Thus, either service quality or price, customer satisfaction is viewed a pre-requisite for customer loyalty and organizational success in the long term (MartínConsuegra, Molina, \& Esteban, 2007; Steinhauser, Janssen, \& Hamm, 2019).
There is a strong relationship among service quality, price, customer satisfaction and WOM. Several empirical studies in the area of assurance service (Allahham \& Aljumaa, 2014; Carvalho, Saldanha, \& Amaral, 2020), hospitality service (Flores, Saldanha, \& Vong, 2020; Minh, Thu Ha, Chi Anh, \& Matsui, 2015) and higher education sector (Chandra, Hafni, Chandra, Purwati, \& Chandra, 2019; Saldanha, 2019) show that service quality has a positive and significant relationship with customer satisfaction. These facts supported the grand theory of SERQUAL coined by Parasuraman et al., (1985), Garvin (1987), as well as Kotler, Kartajaya, \& Setiawan (2019), and others who have examined the relationship between service quality and customer satisfaction concepts.

Nevertheless, the relationship between price and customer satisfaction has a paradox and relatively showing discrepancies between different places and industries. Papafotikas, Chatzoudes, \& Kamenidou (2014) for instance discover that there is a negative relationship between the price and customer satisfaction, while Carvalho et al., (2020) and Bei \& Chiao (2001) found that price has insignificant influence towards customer satisfaction. Thus, lower price does not necessarily mean customers are satisfied. If the service/ product has high quality, it will give a positive impact to customer satisfaction even the price is higher (Cakici, Yildirim, \& Akgunduz, 2019; Makanyeza \& Chikazhe, 2017; Singh, 1990).

This paper also examines two indirect effects: including customer satisfaction effect in the relationship 
Vol. 3, Issue 2, pp. 1-16, 2021

Available online at: https://tljbm.org/jurnal/index.php/tljbm

between (i) service quality and WOM, as well as (ii) price and WOM. According to Susilowati \& Yasri (2019), service quality has a positive relationship with WOM. Similarly, the study of Jiewanto, Laurens, \& Nelloh (2012) recommends that service quality has a positive impact to the image and organizational satisfaction, which then help to stimulate positive WOM (PWOM). This phenomenon suggests that if customers feel satisfied with the quality of service delivered, other dimensions will be impacted positively.

The second indirect effect of customer satisfaction on the relationship between price and WOM is also show a discrepancy. While a study found that customer satisfaction has partial mediation effect (Yasa \& Setiawan, 2018), others revealed that the relationship between price and WOM has a negative effect only for the first-time visitors or users (Matzler et al., 2019). This means price has a potential to initiate PWOM if the service or product performance is beyond customer expectation.

According to Liu \& Lee (2016), service quality is also linked with price, which in turn motivates WOM. The study of Allahham \& Aljumaa (2014) finds that customer satisfaction and price has a positive effect towards WOM. In monopoly market, particularly power supply in TimorLeste, customers have limited options even if they are not satisfied with the price (Carvalho et al., 2020).

In relation to the empirical studies above, this paper seeks to test the relationship between the variables at EDTL.EP in Dili Municipality. More specifically, this paper seeks to identify and explain the influence of (i) service quality, price, and customer satisfaction towards WOM, (ii) service quality and prices towards customer satisfaction, as well as (iii) service quality and price towards WOM with the mediation of customer satisfaction.

\section{Theoretical Frameworks and Hypothesis 2.1. Theoretical Frameworks 2.1.1. Service Quality}

Service quality is defined as the result of comparison between the customers' perception and expectation of a product/ service in relation to various factors. According to Garvin (1987), service quality is measured through 8 dimensions, including performance, features, reliability, conformance, durability, serviceability, aesthetics, and perceived quality. However, according to Parasuraman et al., (1985), these dimensions can be classified into 5 only, including reliability, tangibility, responsiveness, assurance and empathy.

In the essence of measuring service quality, numerous researchers have developed several research scales by combining tangible and intangible dimensions (Carranza, Díaz, \& Martín-Consuegra, 2018). Some scholars suggest that service quality is linked to the outcome of a service's reliability, and the process of service delivery is more concerned with the rest of four elements (Alhkami \&
Alarussi, 2016). For that reason, service providers should be aware of different factors, which customers use to evaluate their products/ services.

Indeed, service quality is one of the most determinants of customer satisfaction in American society (Allahham \& Aljumaa, 2014), and reliability proved to be the biggest contributing factor to service quality (Berry, Parasuraman, \& Zeithaml, 1988; Parasuraman et al., 1985). Tangibility refers to the physical appearance of an organization, including equipment, facilities and employees to deliver its services. The employees' knowledge and skills to ensure the quality of service on time is referred to as responsiveness.

Customers normally prefer to look for the best service provider, and responsiveness denotes the willingness of employees to provide them with a good, quality and fast service (Alhkami \& Alarussi, 2016). Positive perceptions of quality are often generated from how a company can recover quickly and professionally if the employees fail to deliver the service. Hence, Chien \& Chi (2019) underlined that customer satisfaction is influenced by service quality.

\subsubsection{Price}

Price is defined as the buyer's maximum willingness to pay and the seller's minimum willingness to accept (Inoua \& Smith, 2020). It indicates the total financial sacrifice required to obtain a product/ service (Beneke \& Zimmerman, 2014). According to Wolinsky (1983) and Kennedy (1994), price is signals of a product quality, which normally covers the overall cost of productions and distribution chain. Therefore, price should be well calculated and should equivalent to the capacity of product or service received by the customers (Mahoney \& Tang, 2016).

Traditionally, according to Adam Smith's Wealth of Nation (1776) book, labor is referred to as the 'origin' of price where people can make money. The earned amount then will be used to pay after receiving a product/ service. In addition, conventional markets normally dominated by Barter practice - a market system where sellers and buyers make negotiation to exchanges product or service without involving money.

Price is a crucial instrument for both producers and consumers. First, it functions as a reference for the producer as to calculate the value of selling, and for the consumers when evaluating the quality of the products. Secondly, it functions as transaction instrument to facilitate the value transmitted through selling and buying products (Adhikari, 2018). Price becomes an indicator for clients in order to make purchase decision in relation to product utility and compare their purchasing capacity (Kukar-Kinney, Ridgway, \& Monroe, 2012). Nevertheless, price is referred to as an equity for buyers to make comparison between cost and profit, and make evaluation with other buyers who 
Vol. 3, Issue 2, pp. 1-16, 2021

Available online at: https://tljbm.org/jurnal/index.php/tljbm

purchase the same product from different organizations (Zietsman, Mostert, \& Svensson, 2019).

Cost of production, distribution and market demand for the product are important elements for price construction (Schindler \& Schindler, 2011). Price also depending on the quantity of the products in the market cycle (Wagner, 1987). Therefore, in view that price is determined by the producer and is paid by the consumer (Kotler \& Armstrong, 2012), it is often seen a tax from suppliers, particularly in the monopoly market where competition is absent (Inoua \& Smith, 2020). Despites, suppliers should be aware that price contributes heavily to the consumer's perception.

Good price-quality ratio will give better customer satisfaction. According to Matzler et al., (2019), price transparency and reliability is important in the market. Price transparency refers to the capacity of customers know selling price and stock negotiation, and price reliability indicates price consistency. After all, price is not the only factor to determine the level of customer satisfaction (Özkan, Süer, Keser, \& Kocakoç, 2019; Vera, 2015). Particularly in the monopoly market, customers must continue to buy to fulfil their needs even if they are not satisfied with the service or price (Steinhauser et al., 2019).

\subsubsection{Customer Satisfaction}

Customer satisfaction is an expression of happiness or unhappiness of customers after evaluating a product/ service according to their expectations, or a response towards a product/ service (Parasuraman et al., 1994; Rua, de Sousa Saldanha, \& Amaral, 2020). Customer satisfaction is an evaluative judgement post consumption (Fornell, Rust, \& Dekimpe, 2010; Oliver, 1997), and becomes the first key indicator for business (Flores et al., 2020). When customers are satisfied, they will continue to buy the same product/ service, which will increase a company's share in the market (Ennew, Banerjee, \& li, 2000). Thus, customer satisfaction deals with the individual's perceived feelings, either enjoyment or discontentment, after comparing a product/ service's perceived performance with one's expectation (Kotler \& Keller, 2011; Rahman, Hassan, Osman-Gani, Abdel Fattah, \& Anwar, 2017).

According to the disconfirmation paradigm, customer satisfaction is a construction through expectation, performance, disconfirmation, and satisfaction. Expectation of customers is confirmed when a product/ service performs according to their expectations, and disconfirmation become positive when the performance go beyond the customer's expectation (Berlian \& Balqiah, 2019; Churchill Jr \& Surprenant, 1982; Kucukosmanoglu \& Şensoy, 2010).

Satisfaction is the overall objective to purchase a product/ service. Customer satisfaction is the ultimate result where companies are aiming to achieve (Carpenter, 2008; Churchill Jr \& Surprenant, 1982), as to ensure development and bring success to the organization (Taghizadeh, Taghipourian, \& Khazaei, 2013).

Therefore, for customer-centered companies, special attention in satisfying and retaining customers is crucial (Cakici et al., 2019). This often includes improving service and product quality as well as price. Kotler \& Keller (2011) suggest that to ensure customer satisfaction, service quality should start from customers' need and finish at their perceptions regarding the quality of the service.

\subsubsection{Word of Mouth (WOM)}

Word of Mouth (WOM) is the ancient form of communication to transmit information (Dellarocas, 2003). It exceeds the impact marketing efforts (Karlíček, Tomek, \& Kř́žžek, 2014), and has been one of the largest influence for customer to determine where to shop in today's business market (Latif, Ramli, \& Alauddin, 2019; Sukhraj, 2021).

The term has been defined several times, with at least two basic ideas: informal and non-commercial forms of communications. As cited in Iuliana-Raluca (2012), interpretations of WOM covers oral, person to person communication, between a communicator and a receptor, where the latter is perceived as non-commercial in relation to a product/ service (Arndt, 1967), telling dissatisfaction/ unsatisfactory (Richin, 1983; Sing, 1990), or sharing of salient experience (Higie et al., 1987). More recently, WOM is defined as a statement, rationally or non-personal that is conveyed by someone other than the service provider to the customer (Rani \& Usman, 2019).

In this regard, WOM contains negative and positive information. Negative WOM (NWOM) refers to comments of dissatisfaction or frustration about a product/ service (Singh, 1990), and vice versa. Either NWOM or PWOM, both gain momentum differently. Customers who are satisfied normally promote PWOM, and have high likelihood to be loyal (Matzler et al., 2019). To this end, WOM became one the most studied topic in the field of marketing because of the shift that took place in consumers' behavior which have blocked traditional way of marketing communication (Iuliana-Raluca, 2012).

Despite the importance of the concept, WOM is typically not easy to measure, particularly in the service area. Rani \& Usman (2019) suggest dimensions to measure WOM including, first, information from other people, either we directly meet or from social media. Given the fact that WOM is more credible, customers often change their purchase decision after receiving information from other people (Kotler \& Armstrong, 2012). Secondly, WOM can be measured through promotion, and retention. Promotion and retention are two dimensions, which are mutually reinforcing. When a customer is feeling satisfied with a service/ product, it is most likely that he/she will not only desire to tell positive things, but also trying hardly to influence other people to change their decisions and follow his/her recommendation. Thus, WOM contains strong 
Vol. 3, Issue 2, pp. 1-16, 2021

Available online at: https://tljbm.org/jurnal/index.php/tljbm

messages to influence customers decisions to purchase because communicators often using very stimulative information (Karlíček et al., 2014).

In practices, while it lasts longer (Sundaram, Mitra, \& Webster, 1998), some studies find that WOM is the most effective way to influence clients to change brand than formal promotion using newspapers, radio or direct sales (Hepp, 2020; Krishnan \& Nene, 2018; Villanueva, Yoo, \& Hanssens, 2008). Hence, for receptors, communicator normally viewed as independent from the market, and therefore, it gives more credibility to WOM.

\subsubsection{Conceptual Model}

Researcher in this study saw that service quality and price are important factors for the cause of customer satisfaction, and therefore helping to stimulate PWOM. This concept is based on the grand theory of Service Quality (SERVQUAL) coined by Parasuraman et al., (1988; 1994) in relations to customer satisfaction. The relationship between price and WOM is adapted according to the study of Rani \& Usman (2019) and Matzler et al., (2019). Nevertheless, other models developed by Allaham \& Aljumaa (2014), Chaniotakis \& Lymperopoulos (2009), Susilowati \& Yasri (2019) and Carvalho et al., (2020) are also reflected in this study.

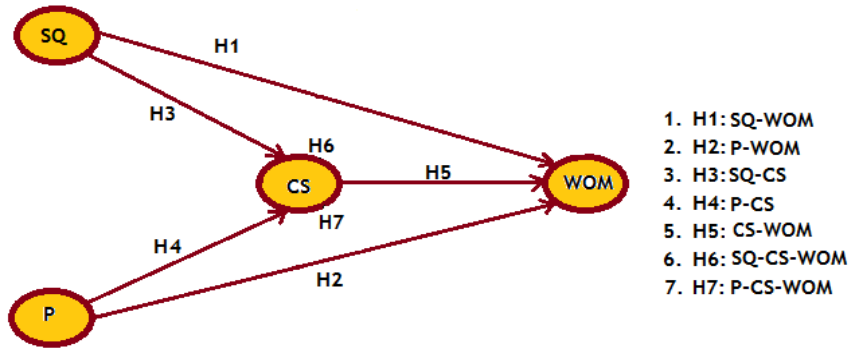

Figure 1. Conceptual Model

(SQ-Service Quality, $P$ - Price, CS - Constumer Satisfaction, and WOM - Word of Mouth).

\subsection{Hypothesis}

\subsubsection{Service Quality and WOM}

Service quality is the most influential factor for WOM. The study of Ennew et al., (2000) finds that PWOM from satisfied customers helps to increase market share. Nevertheless, relevant studies also proved that service quality, particularly empathy (Chaniotakis \& Lymperopoulos, 2009) and attitude, ability, evidence and comfortable (Choudhury, 2011; Chunyan Liu, Dou, Li, \& Cai, 2020) have positive effects on WOM. Better service quality has double benefit in terms of customer retention capacity to maintain customers over time, and acquisition organization strategy to gain new customers. More specifically, the work of Alexandris, Dimitriadis, \&
Markata (2002) confirms that service quality has a positive and significant effect on WOM.

$\mathrm{H}_{1}$ : Service quality has a positive and significant effect to WOM in EDTL.EP.

\subsubsection{Price and WOM}

Besides service quality, price is also an important contributing factor to WOM. According to Yasa \& Setiawan (2018), fair price has a positive and significant influence to WOM. In the tourism industry, the study of Matzler et al., (2019) finds that price is negatively related to WOM for first time visitors and that price has no effect on WOM for repeat visitors. When price is accessible and customers receive better experience, they have more tendency to promote PWOM. However, according to Vera (2015) and Özkan et al., (Özkan et al., 2019), price is not the only factor to determine the level of customer satisfaction. Particularly in the monopoly market, customers must continue to buy the service/ product to fulfil their needs even though they are dissatisfied with the price (Steinhauser et al., 2019).

$\mathrm{H}_{2}$ : Price has a positive and insignificant effect to WOM in EDTL.EP.

\subsubsection{Service Quality and Customer Satisfaction}

In service industries, service quality is proved to be the most determinant factor for customer satisfaction. Empirical studies on insurance services (Allahham \& Aljumaa, 2014; Carvalho et al., 2020), hotel services (Flores et al., 2020; Minh et al., 2015) and also higher education sector (Chandra et al., 2019; Saldanha, 2019) show that service quality has positive and significant influence to customer satisfaction. In the area of telecommunication, Al-Hashedi \& Abkar (2017) reveals that service quality has a positive and significant impact on customer satisfaction, while tangibles and responsiveness have no impact on customer satisfaction. Results from these research support the empirical studies of Parasuraman et al., (1985), Garvin (1987), Kotler, Kartajaya \& Setiawan (2019) which highlight the important relationship of these two variables.

$\mathrm{H}_{3}$ : Service quality has a positive and significant effect to customer satisfaction in EDTL.EP.

\subsubsection{Price and Customer Satisfaction}

Price is considered as the first quality indicator for customers in making purchase decision for a service/ product (Kennedy, 1994; Wolinsky, 1983). Better price will give prime satisfaction to fulfill the customers' needs beyond their expectations. Yasa \& Setiawan (2018), confirms the study of Allahham \& Aljumaa (2014) which discover that product quality and fair pricing have positive and significant influence to customer satisfaction. Standard pricing and accessible often effect customer satisfaction 
Vol. 3, Issue 2, pp. 1-16, 2021

Available online at: https://tljbm.org/jurnal/index.php/tljbm

positively (Ehsani \& Ehsani, 2015; Malik, Ghafoor, \& Iqbal, 2012). These studies however is not in line with the work of Carvalho et al., (2020) in the area of insurance in Timor-Leste which shows that price does not have insignificant effect to customer satisfaction.

$\mathrm{H}_{4}$ : Price has positive and insignificant effect to customer satisfaction in EDTL.EP.

\subsubsection{Customer Satisfaction and WOM}

This study also proposes the hypothesis that customer satisfaction has a significant influence on PWOM. Research from Lovelock \& Yip (1996) suggests that service quality and customer satisfaction which are known to promote PWOM, encourage more positive recommendations for service providers or employers for more improvements (Parasuraman et al., 1988). The formula is that satisfied customers normally become PWOM promoters because the performance of service they have received is often beyond their expectations (Maxham, 2001), and those who spread NWOM reflect the frustration as a method of calling attention to providers for improvements (Anderson, 1996). In this relation, the study of Allahham \& Aljumaa (2014) reveals that customer satisfaction has a direct effect to WOM.

$\mathrm{H}_{5}$ : Customer satisfaction has a positive and significant effect to WOM at EDTL.EP.

\subsubsection{Service Quality, WOM and Customer Satisfaction}

With reference from the above-mentioned hypothesis, it is evident that customers willing to promote WOM due to various factors. Apart from customer satisfaction, Chaniotakis et al., (2009) proves that service quality, particularly empathy, has a direct and positive effect to WOM, and other dimensions will automatically have indirect effect through satisfaction. While Susilowati \& Yasri (2019) also confirms that service quality and customer satisfaction has a positive and significant effect to WOM intention, the study of Jiewanto, Laurens, \& Nelloh (2012) similarly discover that service quality has a positive effect to image and organizational satisfaction, which in turn positively affects WOM.

$\mathrm{H}_{6}$ : There is a positive and significant relation between quality service and WOM with the mediation of customer satisfaction in EDTL.EP.

\subsubsection{Price, WOM and Customer Satisfaction}

Besides product/ service quality, price also become an important element for WOM (Matzler et al., 2019; Yasa \& Setiawan, 2018), and customer satisfaction (Carvalho et al., 2020; Ehsani \& Ehsani, 2015; Malik et al., 2012). The study of Liu \& Lee (2016) stresses that service quality is strongly linked with perception about price, and subsequently motivates WOM. Yet, Allahham \& Aljumaa (2014) also confirms that price and customer satisfaction influence
WOM positively. In the monopoly market, particularly power supply in Timor-Leste, customers have no options but to continue buy the service to fulfil their needs even though they feel satisfied or dissatisfied (Carvalho et al., 2020).

$\mathrm{H}_{7}$ : There is positive and insignificant relation between price and WOM with the mediation of customer satisfaction in EDTL.EP.

\section{Research Method, Data Collection and Analysis}

This study uses quantitative data method, which aims to determine the relationship between two or more variables. The population of this study is customers from Electricidade de Timor-Leste, Empresa Publica (EDTL.EP), in Dili with the total customers of 59,540 [EDTL Report, 2020]. Using Slovin formula and 5\% of margin of error, a total size of 315 samples were derived to respond 43 questions distributed in 4 constructs including service quality, prices, customer satisfaction and word-ofmouth (WOM).

Data was collected using questionnaires because it involves many people, easy, faster and economically more effective (Bailey, 1982). The questionnaires were developed using a five-point Likert-type scale for all items in this study, ranging from $1=$ 'Strongly Disagree' to $5=$ 'Strongly Agree.' Items of service quality and satisfaction adopted from Parasuraman et al., (1988; 1994), while price and WOM is adapted according to the study of Chaniotakis \& Lymperopoulos (2009), Allaham \& Aljumaa (2014), Rani \& Usman (2019), Matzler et al., (2019), Susilowati \& Yasri (2019) and Carvalho et al., (2020).

SMART-PLS 3.0 was used to test validity, reliability and hypothesis as the software has been proved to be good for testing multivariate model, small sample size, formative/ reflective indicators (Hair, Sarstedt, Hopkins, \& Kuppelwieser, 2014). When testing using SMART-PLS, according to Hair et al., (2014) and Saldanha et al., (2019), it should be analyzed through three different stages including (i) Model design and building, (ii) Outer model measurement, and (iii) Inner model measurement. First, the model was built in SMART-PLS based on theoretical and empiric revisions. After designing the conceptual model, secondly, the researcher tested the validity and reliability of the model following the rule of Hair et al., (2014), and then used Cronbach Alpha (CA) and composite reliability (CR) for outer model reliability test. A reliable relationship indicator is seen only when the CR and CA values are greater than 0.70 (Hair et al., 2014; E. Saldanha, 2018).

Nonetheless, validity test is divided into two parts. The first part is called convergent validity, where the test is using outer loading $(\mathrm{OL})$ and average variance extracted (AVE). In these two parameters, the relationship is valid only if the value is higher than 0.7 and 0.5 respectively. The second validity test is called discriminant validity, which involves Fornell-Larcker criterion (FLC) and heterotrait- 
Vol. 3, Issue 2, pp. 1-16, 2021

Available online at: https://tljbm.org/jurnal/index.php/tljbm

monotrait (HTMT) test as per the recommendation of Hair et al., (2017) and Henseler et al., (2015) correspondingly. If the value of FCL and HTMT is less than 0.85 , then it is valid. However, from a discriminant validity point of view, an indicator is valid when the value "root" AVE of an indicator is greater than the value of another indicator (Rua et al., 2020).

Finally, the last stage for SMART-PLS experiment is the testing of hypothesis using path coefficient $\mathrm{T}$ and $\mathrm{P}$ values. In this test, according to Hair et al., (2017) and Saldanha et al., (2019), the relationship is positive and significant only when the $\mathrm{T}$ values greater than 1.96 , and $\mathrm{P}$ values lower than the threshold values of 0.05 .

\subsection{Validity and Reliability}

The validity test uses two methods, namely convergent validity and discriminant validity. The results of convergent validity test using OL and AVE as explained above, is shown in Figure 1. It shows that the OL value of all items in this study is greater than 0.70, except REL, TAN and WOM. However, according to Hair et al., (2014), the value of outer loading (OL) can still be accepted when the research is categorized as an exploratory research, and the outer loadings does not influence on content validity. Based on AVE values, Table 3 shows that all item values were well-above 0.5 as the minimum treshold value stated by Hair et al., (2014).

\section{Results}

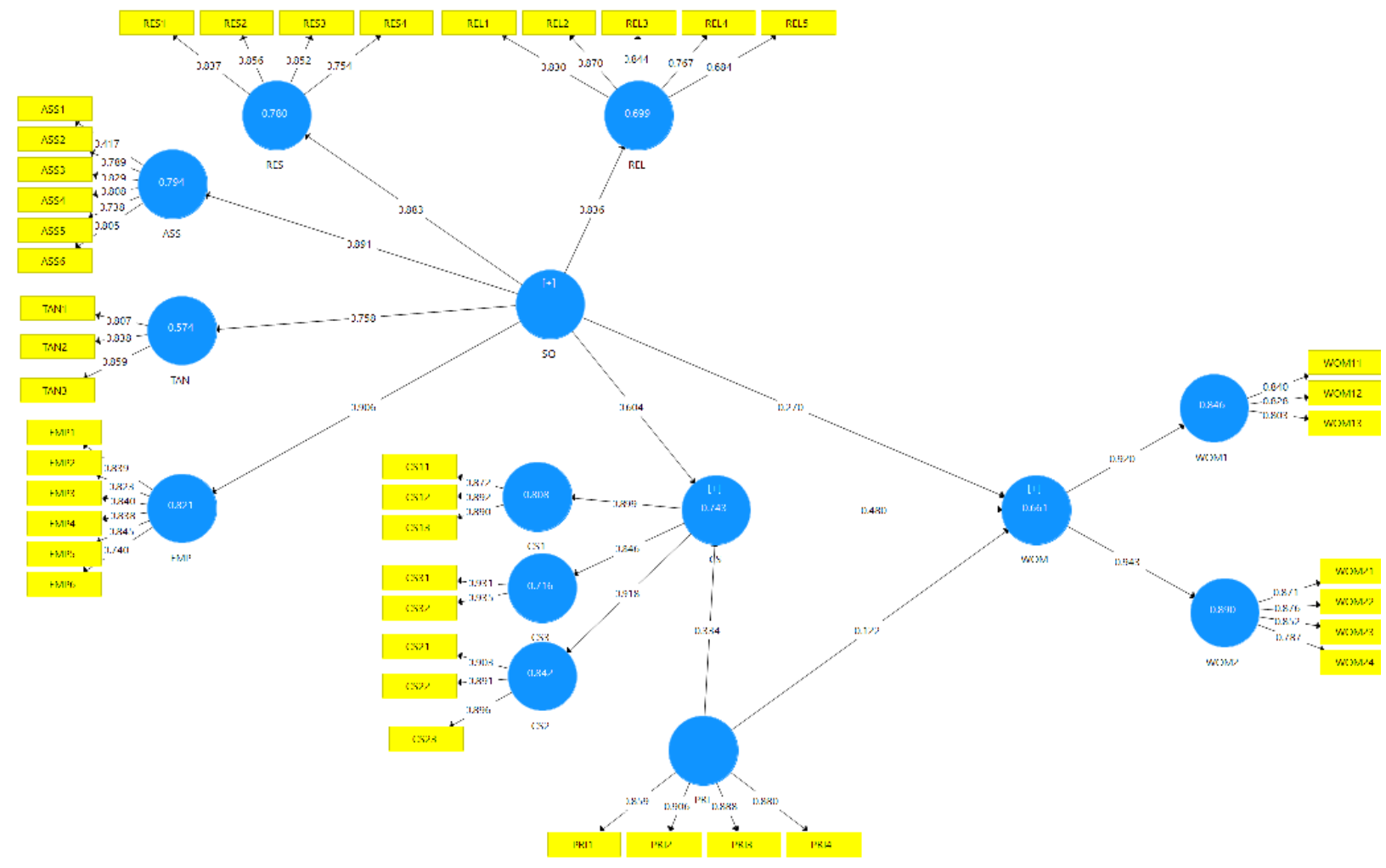

Figure 2. Outer Loading (OL) for Convergent Validity

The result for discriminant validity test using FornellLarcker Criterion (FLC) and heterotrait-monotrait (HTMT) can be seen in Table 1 \& Table 2 respectively. First, the Table 1 shows that the FLC value of all items meeting the criteria of Hair et al., (2014).

Looking at the HTMT value, Table 2 also shows that all items have the value below 0.85, except item CS2, EMP, RES and WOM2. However, the value of these items is recommended to continue used to test the relations between variables because they do not influence content validity as stated by Hair et al., (2014). Hence, all items meeting criteria to test the relationship between variables (inner model measurement). 
Vol. 3, Issue 2, pp. 1-16, 2021

Available online at: https://tljbm.org/jurnal/index.php/tljbm

Table 1. Fornell-Larcker Criterion for Discriminant Validity

\begin{tabular}{|l|l|l|l|l|l|l|l|l|l|l|}
\hline Item & ASS & CS1 & CS2 & CS3 & EMP & PRI & REL & RES & TAN & WOM1 \\
\hline ASS & 0.745 & & & & & & & & & \\
CS1 & 0.699 & 0.884 & & & & & & & & \\
CS2 & 0.691 & 0.757 & 0.897 & & & & & & & \\
\hline CS3 & 0.567 & 0.625 & 0.668 & 0.933 & & & & & & \\
EMP & 0.815 & 0.709 & 0.643 & 0.568 & 0.822 & & & & & \\
PRI & 0.606 & 0.675 & 0.699 & 0.558 & 0.543 & 0.883 & & & & \\
REL & 0.677 & 0.652 & 0.626 & 0.499 & 0.673 & 0.534 & 0.802 & & & \\
\hline RES & 0.709 & 0.676 & 0.684 & 0.590 & 0.767 & 0.550 & 0.734 & 0.826 & & \\
TAN & 0.571 & 0.610 & 0.622 & 0.494 & 0.622 & 0.575 & 0.515 & 0.574 & 0.835 & \\
WOM & 0.679 & 0.680 & 0.718 & 0.714 & 0.678 & 0.651 & 0.618 & 0.629 & 0.552 & \\
WOM1 & 0.596 & 0.593 & 0.630 & 0.606 & 0.614 & 0.601 & 0.556 & 0.572 & 0.523 & 0.824 \\
\hline
\end{tabular}

Table 2. Heterotrait-Monotrait (HTMT) for Discriminant Validity

\begin{tabular}{|l|l|l|l|l|l|l|l|l|l|l|}
\hline Item & ASS & CS1 & CS2 & CS3 & EMP & PRI & REL & RES & TAN & WOM1 \\
\hline CS1 & 0.822 & & & & & & & & & \\
CS2 & 0.801 & 0.870 & & & & & & & & \\
CS3 & 0.663 & 0.728 & 0.773 & & & & & & & \\
EMP & 0.898 & 0.805 & 0.721 & 0.645 & & & & & & \\
PRI & 0.691 & 0.762 & 0.783 & 0.635 & 0.599 & & & & & \\
REL & 0.792 & 0.758 & 0.721 & 0.581 & 0.758 & 0.603 & & & & \\
RES & 0.840 & 0.795 & 0.794 & 0.697 & 0.880 & 0.629 & 0.857 & & & \\
TAN & 0.695 & 0.740 & 0.750 & 0.605 & 0.739 & 0.682 & 0.625 & 0.706 & & \\
WOM1 & 0.736 & 0.725 & 0.764 & 0.749 & 0.732 & 0.720 & 0.671 & 0.705 & 0.672 & \\
WOM2 & 0.764 & 0.766 & 0.798 & 0.828 & 0.723 & 0.682 & 0.671 & 0.689 & 0.609 & 0.894 \\
\hline
\end{tabular}

Table 3. Reliability Test

\begin{tabular}{|c|c|c|c|}
\hline Item & $\begin{array}{c}\text { Cronbach's Alpha } \\
\text { (CA) }\end{array}$ & $\begin{array}{c}\text { Composite Reliability } \\
\text { (CR) }\end{array}$ & $\begin{array}{c}\text { Average Variance } \\
\text { Extracted }\end{array}$ \\
\hline ASS & 0.830 & 0.878 & 0.555 \\
\hline CS1 & 0.861 & 0.915 & 0.782 \\
CS2 & 0.878 & 0.925 & 0.804 \\
\hline CS3 & 0.851 & 0.931 & 0.871 \\
\hline EMP & 0.903 & 0.926 & 0.675 \\
PRI & 0.906 & 0.934 & 0.780 \\
REL & 0.859 & 0.899 & 0.643 \\
\hline RES & 0.844 & 0.895 & 0.682 \\
\hline TAN & 0.783 & 0.873 & 0.697 \\
WOM1 & 0.763 & 0.864 & 0.678 \\
\hline WOM2 & 0.868 & 0.910 & 0.718 \\
\hline
\end{tabular}


Reliability was tested using Cronbach's alpha (CA) parameter and composite reliability (CR). Table 3 shows that $\mathrm{CA}$ and $\mathrm{CR}$ values of items are greater than 0.70 . This means that all indicators in this research model are reliable to test the relationship between variables (inner model measurement).

\subsection{Hypothesis Test}

The last stage of analysis using SMART-PLS 3.0 as stated above is the testing of hypothesis to see the direct effect of service quality and price on WOM, as well as indirect effect of the variables above using the mediation of customer satisfaction. The result of the referred test is
Vol. 3, Issue 2, pp. 1-16, 2021

Available online at: https://tljbm.org/jurnal/index.php/tljbm

shown in Table 4 where in general T Statistic and P Value meet the set criteria.

The first hypothesis to test in this study is to see the direct effect of service quality (SQ) on word of mouth (WOM). In this regards, Table 4 shows that $\mathrm{T}$ value (4.026) is greater than 1.96 and $\mathrm{P}$ value $(0.000)$ is lower than 0,05 - which means service quality (SQ) has a positive and signficant effect on word of mouths (WOM). Therefore, $\mathrm{H}_{1}$ is accepted. The next hypothesis is to test the direct effect of price $(\mathrm{P})$ on WOM, and the result suggests that $\mathrm{T}$ value (2.245) is greater than 1.96 and $\mathrm{P}$ value $(0.025)$ is lower than 0,05 . This means that price $(\mathrm{P})$ has a positive and signficant effect on WOM. Therefore, $\mathrm{H}_{2}$ is accepted.

Table 4. Direct Effect and Indirect Effect for Hypothesis Test (T and P values)

\begin{tabular}{|l|c|c|c|c|c|c|}
\hline & $\begin{array}{c}\text { Original } \\
\text { Sample } \\
(\mathrm{O})\end{array}$ & $\begin{array}{c}\text { Sample } \\
\text { Mean (M) }\end{array}$ & $\begin{array}{c}\text { Standard } \\
\text { Deviation } \\
\text { (STDEV) }\end{array}$ & $\begin{array}{c}\text { T Statistics } \\
(|\mathrm{O} / \mathrm{STDEV}|)\end{array}$ & P Values & Note \\
\hline SQ > WOM & 0.270 & 0.271 & 0.067 & 4.026 & 0.000 & Significant \\
\hline PRI > WOM & 0.122 & 0.117 & 0.054 & 2.245 & 0.025 & Significant \\
\hline SQ > CS & 0.604 & 0.617 & 0.041 & 14.757 & 0.000 & Significant \\
\hline PRI > CS & 0.334 & 0.324 & 0.046 & 7.311 & 0.000 & Significant \\
\hline CS > WOM & 0.480 & 0.486 & 0.073 & 6.538 & 0.000 & Significant \\
\hline SQ > CS > WOM & 0.290 & 0.300 & 0.049 & 5.890 & 0.000 & Significant \\
\hline PRI > CS > WOM & 0.160 & 0.158 & 0.034 & 4.717 & 0.000 & Significant \\
\hline
\end{tabular}

Table 4 shows the relationship of both service quality (SQ) and price (P) to customer satisfaction (SC) are positive and significant, because the table shows that $\mathrm{T}$ value registered 14.757 and 7.311 which are greater than 1.96 , and $\mathrm{P}$ value 0.000 for both variables are lower than 0,05 . These figures mean that both service quality (SQ) and price $(\mathrm{P})$ have positive and significant effects towards customer satisfaction (SC). Therefore, $\mathrm{H}_{3} \quad \& \quad \mathrm{H}_{4}$ are supported. The fifth hypothesis is to test the direct effect of customer satisfaction (CS) on WOM, and the result suggests that $T$ value (6.538) is greater than 1.96 and $P$ value $(0.000)$ is lower than 0.05 . This means that customer satisfaction (CS) has a positive and signficant effect on WOM. Thus, $\mathrm{H}_{5}$ is accepted.

This study also used SMART-PLS 3.0 to test the mediating effect of customer satisfaction (CS) on the relationship between service quality (SQ) and word of mouth (WOM). Table 4 shows that $\mathrm{T}$ value (5.890) is greater than 1.96 and $\mathrm{P}$ value (0.000) is lower than 0.05 . This means that customer satisfaction (CS) has a positive and signficant effect in mediating the relationship between CS and WOM. Thus, $\mathrm{H}_{6}$ is accepted. The last hypothesis to test the mediating effect of customer satisfaction (CS) in the relationship price (P) and word of mouth (WOM). Table 4 depicts that $T$ value (4.717) is greater than 1.96 and $P$ value
(0.000) is lower than 0,05 . This means that customer satisfaction (CS) has a positive and signficant effect in mediating the relationship between price $(\mathrm{P})$ and WOM. Thus, $\mathrm{H}_{7}$ is supported

\section{Discussion}

The first objective of this study was to examine the influence of service quality to WOM, and the result shows that service quality has a positive and significant effect to WOM. Assurance and empathy dimensions in particular, registered $58.3 \%$ and $54.8 \%$ respectively, and both appear to be the most contributing factors for service quality in EDTL.EP. This outcome reinforces the overarching idea that in the business market, nothing is more important than the customers satisfaction (Carpenter, 2008; Carvalho et al., 2020; Churchill Jr \& Surprenant, 1982).

For customers, the desire of seeking for a better product/ service quality to fulfill their desires or needs according to their expectations is predominant. Thus, service quality has a strong influence to WOM (Bharadwaj, Varadarajan, \& Fahy, 1993). Customers who feel satisfied with a particular service/ product will not only show their loyalty, but also spread positive WOM which in return will help to increase the market share and profitability of that 
particular organization (Ennew et al., 2000; Matzler et al., 2019).

Based on PESTEL analysis, both political and legality aspects give greater advantages to EDTL.EP (de jure monopoly) through Decree Law No. 29/2020. This means the government has a given a unique mandate only to EDTL.EP to provide the service for everyone, therefore there is no competitor in the market. As such, the monopoly system is often criticized because the government prevent new entrants in the market to make innovations (Riggs \& Bonk, 2008), and automatically gives opportunity to company to exploit the customers (Mussa \& Rosen, 1978).

The second objective of this study was to examine the influence of price $(\mathrm{P})$ to word of mouth (WOM). The result shows that price $(\mathrm{P})$ has a positive and significant effect to WOM, which reinforces the work of Yasa \& Setiawan (2018), as well as Matzler et al., (2019). When there is a better price and receiving better experience, customers will feel satisfied and subsequently stimulates PWOM. In this research, the most contributing factor of price to WOM is affordable price $(51 \%)$ then followed by fair price $(45 \%)$. Normally, repeat buyers have less price sensitivity compared to the new ones (Matzler et al., 2019). Yet, although $95 \%$ classified as repeat buyers, EDTL.EP clients continue to insist for a better pricing. Thus, price is an important variable for customers to consider in the market. Nevertheless, for new buyers, involvement in WOM is very helpful particularly listening to their relatives who they already have trust in them (Rani \& Usman, 2019; William, 2017).

Furthermore, this paper also aimed to evaluate the relationship between service quality (SQ) and customer satisfaction (CS), and the result suggests that service quality has a positive and significant influence towards customer satisfaction. This outcome is in line with previous studies which suggest that service quality is important antecedents for customer satisfaction (Cronin \& Taylor, 1992; Oliver, 1997; Parasuraman et al., 1988; Spreng \& Mackoy, 1996). Statistics also shows that, out of the five (5) aspects of SERVQUAL, assurance received the highest value (58.3\%) and reliability received lowest value (49\%). Yet, while $30 \%$ of respondent chose to be neutral, it can be explained in two ways: first, perhaps the demand for the company's service is already overwhelmed, and therefore, secondly, the customer is no longer become an important factor for the market.

The fourth objective is to examine the relations between price (P) and customer satisfaction (CS). The result in shown in Table 4 suggests that price $(\mathrm{P})$ has a positive and significant effect to customer satisfaction. That out of 315 respondents in this research, only $47 \%$ often speak positively about EDTL.EP. This outcome is in line with the work of Malik et al., (2012), Ehsani \& Ehsani (2015) and Steinhauser et al., (2019) which suggest that standard pricing will stimulate customer satisfaction.
However, this study is not in line with other researches, which indicated that price does not have a significant influence on customer satisfaction (Carvalho et al., 2020; Papafotikas et al., 2014) because price is not the only determining factor in satisfying customer demand (Özkan et al., 2019; Vera, 2015). These studies stress that better product quality, supported with better service delivery will positively impact customers satisfaction, even though the price is higher than expected (Cakici et al., 2019; Makanyeza \& Chikazhe, 2017; Singh, 1990).

The fifth objective of this study is to examine the relationship between customer satisfaction (CS) and WOM. The analysis result suggests that customer satisfaction (CS) has a positive and significant effect to WOM. This outcome fortifies the study of Lovelock \& Yip (1996) which indicated that service quality and customer satisfaction promote WOM. Hence, while making recommendations to service provider or employer (Parasuraman et al., 1988), customers often talk positively because performance of the service/ product according to or beyond their expectations (Maxham, 2001). The average customer satisfaction across the three dimensions of WOM: information, retention and recommendations, is $55.5 \%$, which means most of the respondents feeling satisfied with the service. However, such circumstances are often dynamic, and in a free or competitive market, customers normally choose for the better ones.

The sixth objective of this study is to test the effect of mediating variable of customer satisfaction for the relationship between service quality (SC) and WOM. The result shows that customer satisfaction (CS) has a significant effect on the relationship between service quality and WOM. This means that customer satisfaction help to raise the level of WOM, if the service quality is improved. This finding reinforces the study of Jiewanto et al., (2012) and Susilowati \& Yasri (2019) which show that organizational satisfaction is important to ensure service quality and has a positive impact towards WOM.

Finally, this study is to test the effect of mediating variable of customer satisfaction for the relationship between price (P) and WOM. The outcome suggests that customer satisfaction (CS) has a significant effect on the relationship between price and WOM. It means that respondents can speak positively about EDTL.EP if they feel satisfied with the service, even though they have to pay more than expected. The finding also in line with previous empirical studies which indicated that, apart from service quality, price is an important measurement to customer satisfaction (Carvalho et al., 2020; Ehsani \& Ehsani, 2015; Malik et al., 2012) and WOM (Matzler et al., 2019; Yasa \& Setiawan, 2018). Hence, service quality is interconnected with perception about price, which subsequently stimulates WOM. 
Vol. 3, Issue 2, pp. 1-16, 2021

Available online at: https://tljbm.org/jurnal/index.php/tljbm

\section{Conclusion and Implications}

In today's business market, word of mouth (WOM) has been seen as the most influential approach in product/ service marketing. Nevertheless, both service quality and price are important elements customer satisfaction, which in turn will help WOM positively. Therefore, many researchers have focus their studies on the relationship between these variables to gain a better understanding about WOM.

In this regard, several empirical studies suggest that there are discrepancies of outcomes in the relationship between service quality, price, customer satisfaction and WOM across industries, places, and times. This research, however, confirms that both service quality and price have positive and significant effect towards WOM in EDTL.EP Dili. The findings also suggest that customer satisfaction plays important role in meditating the relationship of service quality, price and WOM.

This implies that every customer will definitely spread WOM. However, satisfied customers are more likely to speak positively about the company (PWOM) than those who are dissatisfied. Nevertheless, in monopoly market such as power supply in Timor-Leste, customers have no options to choose, but to continue use the service to fulfil their needs even though they are not happy about the service or disagree with the price.

After all, the current study contributes to the existing discussion and empirical studies about service quality, price and customer satisfaction as well as WOM in the modern market. It is expected that top managers in practice will take additional reference from this finding as to improve their service quality and price setting to enhance customer satisfaction and safeguard the sustainability of their organizations.

\section{Limitation and Future Research}

The present research was undertaken to test the relationship between service quality, price and word of mouth (WOM), and employing customer satisfaction as a mediating effect. It noted that this approach may be too narrow, but there are proposed options to enrich in future studies where elements such as innovation and differentiation can also be used as mediating variables.

Nevertheless, this study uses quetionnaire as an important instrument to collect data, which means the result is highly dependents on the answers from the respondents. This method is often envitably creates bias because there is no other instruments to recheck and control the validity of the answers from the same respondents.

Moreover, the outcome of this study cannot be generalized to other types of industries, given that it was conducted only in a 'monopolized' state-owned power supply enterprise and respondents were concentrated on the capital of Dili. Hence, for better data generalization, further studies need to be carried out in other types of industries and it is highly recommended to consider respondents outside the capital.

In short, this study only utilizes periodical data to observe the changes of a period for customer behavior about service quality, price, customer satisfaction and WOM. It is highly recommended that a longitudinal approach or continuous observation is required in future studies to obtain a better data for comparison and therefore for a better generalization.

\section{References}

Adhikari, A. (2018). Strategic marketing issues in emerging markets. Springer.

Al-Hashedi, A. H., \& Abkar, S. A. (2017). The Impact of Service Quality Dimensions on Customer Satisfaction in Telecom Mobile Companies in Yemen. American Journal of Economics, 2017(4), 186-193. https://doi.org/10.5923/j.economics.20170704.04

Alexandris, K., Dimitriadis, N., \& Markata, D. (2002). Can perceptions of service quality predict behavioral intentions? An exploratory study in the hotel sector in Greece. Managing Service Quality: An International Journal, 12(4), 224-231. https://doi.org/10.1108/09604520210434839

Alhkami, A. A., \& Alarussi, A. S. (2016). Service Quality Dimensions and Customer Satisfaction in Telecommunication Companies. Asian Journal of Business and Management, 04(03), 117-126.

Allahham, A., \& Aljumaa, A. (2014). Analyzing Antecedents of Customer Satisfaction and its Impact on Word of Mouth Communication in Life Insurance Services. International Journal of Management Sciences and Business Research, 3(4).

Anderson, W. (1996). Customer Satisfaction and Price Tolerance. Marketing Letters, 7(3), 265-274.

Bailey, K. D. (1982). Methods of Social Research. New York: A Division of Macmillan Publishing Co. Inc.

Bei, L.-T., \& Chiao, Y.-C. (2001). An integrated model for the effects of perceived product, perceived service quality, and perceived price fairness on consumer satisfaction and loyalty. Journal of Consumer Satisfaction, Dissatisfaction and Complaining Behavior, 14, 125-140. Retrieved from https://search.proquest.com/openview/143f32c2397741c88eb49 abacf $11694 \mathrm{c} / 1$ ?pqorigsite $=$ gscholar $\& \mathrm{cbl}=46531$

Beneke, J., \& Zimmerman, N. (2014). Beyond private label panache: the effect of store image and perceived price on brand prestige. Journal of Consumer Marketing, 31(4), 301-311. https://doi.org/doi:10.1108/jcm-12-2013-0801

Berlian, P. A., \& Balqiah, T. E. (2019). Understanding the Benefit of Satisfaction Toward Mobile Shopping Applications. 348(APRiSH 2018), 137-144.

Berry, L. L., Parasuraman, A., \& Zeithaml, V. A. (1988). 
Vol. 3, Issue 2, pp. 1-16, 2021

Available online at: https://tljbm.org/jurnal/index.php/tljbm

SERVQUAL: A multiple-item scale for measuring consumer perceptions of service quality. Journal of Retailing, Vol. 64, pp. $12-40$.

Bharadwaj, S. G., Varadarajan, P. R., \& Fahy, J. (1993). Sustainable Competitive Advantage in Service Industries: A Conceptual Model and Research Propositions. Journal of Marketing, 57(4), 83-99. https://doi.org/10.2307/1252221

Cakici, A. C., Yildirim, O., \& Akgunduz, Y. (2019). The impact of perceived price justice and satisfaction on loyalty: the mediating effect of revisit intention. Tourism Review, 74(3), 443-462. https://doi.org/10.1108/TR-02-2018-0025

Carpenter, J. M. (2008). Consumer shopping value, satisfaction and loyalty in discount retailing. Journal of Retailing and Consumer Services, 15(5), 358-363. https://doi.org/10.1016/j.jretconser.2007.08.003

Carranza, R., Díaz, E., \& Martín-Consuegra, D. (2018). The influence of quality on satisfaction and customer loyalty with an importance-performance map analysis: Exploring the mediating role of trust. Journal of Hospitality and Tourism Technology, 9(3), 380-396. https://doi.org/10.1108/JHTT-09-2017-0104

Carvalho, H. de F., Saldanha, E. de S., \& Amaral, A. M. (2020). The Mediation Effect of Customer Satisfaction on the Relationship Between Service Quality and Customer Loyalty. Journal of Management and Strategy, 2(1), 14-26. https://doi.org/https://doi.org/10.51703/bm.v2i2.18

Chandra, T., Hafni, L., Chandra, S., Purwati, A. A., \& Chandra, J. (2019). The influence of service quality, university image on student satisfaction and student loyalty. Benchmarking, 26(5), 1533-1549. https://doi.org/10.1108/BIJ-07-2018-0212

Chaniotakis, I. E., \& Lymperopoulos, C. (2009). Service quality effect on satisfaction and word of mouth in the health care industry. Managing Service Quality, 19(2), 229-242. https://doi.org/10.1108/09604520910943206

Chien, L. H., \& Chi, S. Y. (2019). Corporate image as a mediator between service quality and customer satisfaction: difference across categorized exhibitors. Heliyon, 5(3), e01307. https://doi.org/10.1016/j.heliyon.2019.e01307

Choudhury, K. (2011). Service Quality and WOM (Word-ofMouth). International Journal of Customer Relationship Marketing and Management, 2(2), 63-87. https://doi.org/10.4018/jcrmm.2011040105

Churchill Jr, G. A., \& Surprenant, C. (1982). An investigation into the determinants of customer satisfaction. Journal of Marketing Research, 19(4), 491-504.

Cronin, J. J., \& Taylor, S. A. (1992). Measuring service quality: A reexamination and extension. Journal of Marketing, 56(3), 5568.

Dellarocas, C. (2003). The digitization of word of mouth: Promise and challenges of online feedback mechanisms. Management Science, 49(10), $1407-1424$ https://doi.org/10.1287/mnsc.49.10.1407.17308
Ehsani, Z., \& Ehsani, M. H. (2015). Effect of quality and price on customer satisfaction and commitment in Iran auto industry. International Journal of Flexible Manufacturing Systems, 3(3-4), 251-274.

Ennew, C. T., Banerjee, A. K., \& li, D. (2000). Managing word of mouth communication: Empirical evidence from India. International Journal of Bank Marketing, 18(2), 75-83. https://doi.org/10.1108/02652320010322985

Flores, A. F., Saldanha, E. de S., \& Vong, M. F. . (2020). The Mediation Effect of Customer Satisfaction on the Relationship Between Service Quality and Customer Loyalty. Journal of Management and Strategy, 2(1), 9. Retrieved from https://tljbm.org/jurnal/index.php/tljbm/article/view/22

Fornell, C., Rust, R. T., \& Dekimpe, M. G. (2010). The Effect of Customer Satisfaction on Consumer Spending Growth. XLVII(February), 28-35.

Garvin, D. (1987). Competing on the eight dimensions of quality. Harv. Bus. Rev., 101-109.

Hair, J., Sarstedt, M., Hopkins, L., \& Kuppelwieser, V. (2014). Partial least squares structural equation modeling (PLS-SEM): An emerging tool in business research. European Business Review, 26(2), 106-121. https://doi.org/10.1108/EBR-10-20130128

Hair, J., Sarstedt, M., Ringle, C., \& Gudergan, S. (2017). Advanced Issues in Partial Least Squares Structural Equation Modeling. Sage.

Hepp, A. (2020). Katz, Elihu/Lazarsfeld, Paul F. (1955): Personal Influence. The Part Played by People in the Flow of Mass Communication. In Key Works of Network Analysis, (Eds, Holzer, B. \& Stegbauer, C.) Springer VS, Wiesbaden (pp. 293296). https://doi.org/10.1007/978-3-658-21742-6

Inoua, S. M., \& Smith, V. L. (2020). Adam Smith's Theory of Value: A Mathematical Statement of His Market Price Discovery Process.

Iuliana-Raluca, G. (2012). Word-of-mouth communication: a theoretical review. Marketing and Management of Innovations, (1), 132-139.

Jiewanto, A., Laurens, C., \& Nelloh, L. (2012). Influence of Service Quality, University Image, and Student Satisfaction toward WOM Intention: A Case Study on Universitas Pelita Harapan Surabaya. Procedia - Social and Behavioral Sciences, 40, 16-23. https://doi.org/10.1016/j.sbspro.2012.03.155

Karlíček, M., Tomek, I., \& Křížek, M. (2014). Word-of-Mouth Marketing: An Integrated Model $\square$. (March).

Kennedy, P. W. (1994). Word-of-Mouth Communication and Price as a Signal of Quality. Economic Record, 70(211), 373380. https://doi.org/10.1111/j.1475-4932.1994.tb01856.x

Kotler, \& Armstrong, G. (2012). Principles of Marketing 14th Edition New Jersey: Pearson Prentice Inc. 
Vol. 3, Issue 2, pp. 1-16, 2021

Available online at: https://tljbm.org/jurnal/index.php/tljbm

Kotler, P., Kartajaya, H., \& Setiawan, I. (2019). Marketing 3.0: From products to customers to the human spirit. In Marketing Wisdom (pp. 139-156). Springer.

Kotler, P., \& Keller, K. (2011). Marketing management 14th edition. prentice Hall.

Krishnan, S., \& Nene, C. L. (2018). Word of Mouth Marketing Strategy. International Journal of Computer Applications, 182(2), 1-6. https://doi.org/10.5120/ijca2018917447

Kucukosmanoglu, A. N., \& Şensoy, E. (2010). Customer Satisfaction: a Central Phenomenon in Marketing. Master, (January), $\quad 56 . \quad$ Retrieved from http://www.academia.edu/1977823/CUSTOMER_SATISFACTI ON_A_CENTRAL_PHENOMENON_IN_MARKETING

Kukar-Kinney, M., Ridgway, N. M., \& Monroe, K. B. (2012). The role of price in the behavior and purchase decisions of compulsive buyers. Journal of Retailing, 88(1), 63-71.

Latif, R. A., Ramli, N. B., \& Alauddin, A. N. M. (2019). Relationship Between Word of Mouth (WOM) Communication and Brand Equity of Sport Products Among Consumers in Kuantan, Pahang. International Journal of Social Sciences and Management, 6(2), 28-34. https://doi.org/10.3126/ijssm.v6i2.23545

Liu, Chih, \& Lee, T. (2016). Service quality and price perception of service: Influence on word-of-mouth and revisit intention. Journal of Air Transport Management, 52, 42-54. https://doi.org/10.1016/j.jairtraman.2015.12.007

Liu, Chunyan, Dou, X., Li, J., \& Cai, L. A. (2020). Analyzing government role in rural tourism development: An empirical investigation from China. Journal of Rural Studies, 79(August), 177-188. https://doi.org/10.1016/j.jrurstud.2020.08.046

Lovelock, C. H., \& Yip, G. S. (1996). Developing Global Strategies for Service Businesses. California Management Review, 38(2), 64-86. https://doi.org/10.2307/41165833

Mahoney, L. M., \& Tang, T. (2016). Strategic social media: From marketing to social change. John Wiley \& Sons.

Makanyeza, C., \& Chikazhe, L. (2017). Mediators of the relationship between service quality and customer loyalty: Evidence from the banking sector in Zimbabwe. International Journal of Bank Marketing, 35(3), 540-556. https://doi.org/10.1108/IJBM-11-2016-0164

Malik, M. E., Ghafoor, M. M., \& Iqbal, H. K. (2012). Impact of Brand Image , Service Quality and price on customer satisfaction in Pakistan Telecommunication sector. 3(23), 123-129.

Martín-Consuegra, D., Molina, A., \& Esteban, Á. (2007). An integrated model of price, satisfaction and loyalty: An empirical analysis in the service sector. Journal of Product and Brand Management, 16(7), 459-468. https://doi.org/10.1108/10610420710834913

Matzler, K., Teichmann, K., Strobl, A., \& Partel, M. (2019). The effect of price on word of mouth: First time versus heavy repeat visitors. Tourism Management, 70(September 2017), 453-459. https://doi.org/10.1016/j.tourman.2018.09.013

Maxham, J. G. (2001). Service recovery's influence on consumer satisfaction, positive word-of-mouth, and purchase intentions. Journal of Business Research, 54(1), 11-24. https://doi.org/10.1016/S0148-2963(00)00114-4

Minh, N. H., Thu Ha, N., Chi Anh, P., \& Matsui, Y. (2015). Service quality and customer satisfaction: A case study of hotel industry in Vietnam. Asian Social Science, 11(10), 73-85. https://doi.org/10.5539/ass.v11n10p73

Mussa, M., \& Rosen, S. (1978). Monopoly and product quality. Journal of Economic Theory, 18(2), 301-317. https://doi.org/10.1016/0022-0531(78)90085-6

Ng, S., David, M. E., \& Dagger, T. S. (2011). Generating positive word-of-mouth in the service experience. Managing Service Quality, 21(2), 133-151. https://doi.org/10.1108/09604521111113438

Nieto, J., Hernández-Maestro, R. M., \& Muñoz-Gallego, P. A. (2014). Marketing decisions, customer reviews, and business performance: The use of the Toprural website by Spanish rural lodging establishments. Tourism Management, 45, 115-123. https://doi.org/10.1016/j.tourman.2014.03.009

Oliver, R. L. (1997). Satisfaction: A Behavioral Perspective on the Consumer. Routledge.

Özkan, P., Süer, S., Keser, İ. K., \& Kocakoç, İ. D. (2019). The effect of service quality and customer satisfaction on customer loyalty: The mediation of perceived value of services, corporate image, and corporate reputation. International Journal of Bank Marketing, 38(2), 384-405. https://doi.org/10.1108/IJBM-032019-0096

Papafotikas, I., Chatzoudes, D., \& Kamenidou, I. (2014). Purchase Decisions of Greek Consumers: An Empirical Study. Procedia Economics and Finance, 9(14), 456-465. https://doi.org/10.1016/s2212-5671(14)00047-1

Parasuraman, A., Zeithaml, V. A., \& Berry, L. L. (1985). A Conceptual Model of Service Quality and Its Implications for Future Research. Journal of Marketing, 49(4), 41-50. https://doi.org/10.1177/002224298504900403

Parasuraman, A., Zeithaml, V. A., \& Berry, L. L. (1988). SERVQUAL: A multiple- Item Scale for measuring consumer perceptions of service quality. (January).

Parasuraman, A., Zeithaml, V. A., \& Berry, L. L. (1994). Alternative scales for measuring service quality: A comparative assessment based on psychometric and diagnostic criteria. Journal of Retailing, 70(3), 201-230. https://doi.org/10.1016/00224359(94)90033-7

Rahman, M. S., Hassan, H., Osman-Gani, A., Abdel Fattah, F. A. M., \& Anwar, M. A. (2017). Edu-tourist's perceived service quality and perception - the mediating role of satisfaction from foreign students' perspectives. Tourism Review, 72(2), 156-170. 
Vol. 3, Issue 2, pp. 1-16, 2021

Available online at: https://tljbm.org/jurnal/index.php/tljbm

https://doi.org/10.1108/TR-12-2016-0057

Rahman, M. S., Hassan, H., Osman-Gani, A., Fattah, F. A. M. A., \& Anwar, M. A. (2017). Edu-tourist's perceived service quality and perception-the mediating role of satisfaction from foreign students' perspectives. Tourism Review.

Rani, A., \& Usman, O. (2019). The Influence of Service Quality, Customer Satisfaction, Price, and Word of Mouth on Repurchase Interests in Drugstore. SSRN Electronic Journal. https://doi.org/10.2139/ssrn.3311507

Riggs, T., \& Bonk, M. (2008). Everyday finance: Economics, personal money management, and entrepreneurship (Vol. 2). Detroit, Michigan: Gale Cengage Learning, 2.

Rua, S., de Sousa Saldanha, E., \& Amaral, A. M. (2020). Examining the Relationships between Product Quality, Customer Satisfaction and Loyalty in the Bamboo Institute, Dili, TimorLeste. Timor Leste Jornal of Business and Management, 2(1), 33 44.

Saldanha, E. (2018). The Role of Business Strategy in Mediating the Relationship Between Industrial Competition and Performances: A Study in the Higher Education Industry in Timor-Leste. European Journal of Business and Management, $152-172$

Saldanha, E. de S., Rahyuda, I. K., Yasa, N. N. K., \& Sukaatmadja, I. P. G. (2019). Industrial Competition, Hybrid Strategy and Industrial Performance: Study in Higher Education Industry in Timor-Leste. Journal of Engineering and Applied Sciences, 14(8), 2456-2464.

Saldanha, E. S. (2019). The Mediation Effects of Business Strategy on the Relations between Industrial Competition and Performance. Timor Leste Journal of Business and Management, 1(June), 1-11. https://doi.org/10.51703/bm.v1i1.6

Schindler, R. M., \& Schindler, R. (2011). Pricing strategies: a marketing approach. sage.

Singh, J. (1990). Voice, exit, and negative word-of-mouth behaviors: An investigation across three service categories. Journal of the Academy of Marketing Science, 18(1), 1-15. https://doi.org/10.1007/BF02729758

Spreng, R. A., \& Mackoy, R. D. (1996). An empirical examination of a model of perceived service quality and satisfaction. Journal of Retailing, 72(2), 201-214. https://doi.org/10.1016/S0022-4359(96)90014-7

Steinhauser, J., Janssen, M., \& Hamm, U. (2019). Consumers' purchase decisions for products with nutrition and health claims: What role do product category and gaze duration on claims play? Appetite, 141(January), 104337. https://doi.org/10.1016/j.appet.2019.104337

Sukhraj, R. (2021). IMPACT: WOM Marketing Strategies (Infografic). Retrieved from https://www.impactplus.com/blog/wordof-mouth-marketing-strategies-infographic

Sundaram, D. S., Mitra, K., \& Webster, C. (1998). Word-ofMouth Communications: A Motivational Analysis. 25.

Susilowati, Y., \& Yasri, Y. (2019). The Effect of Service Quality and Customer Satisfaction Toward Word of Mouth Intention. 64, 677-685. https://doi.org/10.2991/piceeba2-18.2019.52

Taghizadeh, H., Taghipourian, M. J., \& Khazaei, A. (2013). The effect of customer satisfaction on word of mouth communication. Research Journal of Applied Sciences, Engineering and Technology, 5(8), https://doi.org/10.19026/rjaset.5.4698

Vera, J. (2015). Perceived brand quality as a way to superior customer perceived value crossing by moderating effects. Journal of Product \& Brand Management, 24(2), 147-156. https://doi.org/https://doi.org/10.1108/JPBM-04-2014-0551

Villanueva, J., Yoo, S., \& Hanssens, D. M. (2008). The Impact of Marketing-Induced Versus Word-of-Mouth Customer Acquisition on Customer Equity Growth. XLV(February), 48-59.

Wagner, W. B. (1987). The Changing Price Dimension in Purchasing. European Journal of Marketing, 21(1), 5-13. https://doi.org/10.1108/EUM0000000004674

William, M. C. (2017). Positive Versus Negative Word-ofmouth: Effects on Receivers. Academy of Marketing Studies Journal, 21(2), 1-5.

Wolinsky, A. (1983). Prices of as Signals Quality Product. Review of Economic Studies, 50(4), 647-658.

Yasa, I. N. W., \& Setiawan, Y. P. (2018). The role of satisfaction in mediating product quality and price fairness towards word of mouth: study of pelinggih products in Gianyar regency, Indonesia. International Journal of Economics, Commerce and Management, VI(11), 348-364. Retrieved from http://ijecm.co.uk/wp-content/uploads/2018/11/61122.pdf

Zietsman, M. L., Mostert, P., \& Svensson, G. (2019). Perceived price and service quality as mediators between price fairness and perceived value in business banking relationships. International Journal of Bank Marketing, 3(1), 2-19. 


\section{Appendix}

Appendix A1. Repondents perceptions in percentage and mean of all items of service quality (SQ)

\begin{tabular}{|c|c|c|c|c|c|c|c|}
\hline \multirow{3}{*}{$\begin{array}{c}\text { Items } \\
\text { SQ1 - Reliabilit }\end{array}$} & \multicolumn{5}{|c|}{ Frequency $(\%)$} & \multirow{3}{*}{ Total $(4+5)$} & \multirow[b]{2}{*}{ Mean } \\
\hline & 1 & 2 & 3 & 4 & 5 & & \\
\hline & & & & & & & \\
\hline REL1 & 7.3 & 12.7 & 27.0 & 32.4 & 20.6 & 53.0 & 3.46 \\
\hline REL2 & 5.7 & 17.1 & 28.9 & 30.2 & 18.1 & 48.3 & 3.38 \\
\hline REL3 & 3.8 & 12.7 & 26.7 & 34.6 & 22.2 & 56.8 & 3.59 \\
\hline REL4 & 7.9 & 18.1 & 28.6 & 31.1 & 14.3 & 45.4 & 3.26 \\
\hline REL5 & 9.2 & 16.2 & 33.0 & 26.3 & 15.2 & 41.6 & 3.22 \\
\hline Sub-Total & 34.0 & 76.8 & 144.1 & 154.6 & 90.5 & 245.1 & 16.9 \\
\hline Average & 6.8 & 15.4 & 28.8 & 30.9 & 18.1 & 49.0 & 3.4 \\
\hline \multicolumn{8}{|c|}{ SQ2 - Responsiveness } \\
\hline RES1 & 3.8 & 14.3 & 26.3 & 34.6 & 21.0 & 55.6 & 3.55 \\
\hline RES2 & 7.0 & 16.5 & 30.2 & 33.3 & 13.0 & 46.3 & 3.29 \\
\hline RES3 & 3.5 & 14.6 & 28.6 & 34.9 & 18.4 & 53.3 & 3.50 \\
\hline Sub-Total & 14.3 & 45.4 & 85.1 & 102.9 & 52.4 & 155.2 & 10.3 \\
\hline Average & 4.8 & 15.1 & 28.4 & 34.3 & 17.5 & 51.7 & 3.4 \\
\hline \multicolumn{8}{|c|}{ SQ3 - Assurance } \\
\hline ASS1 & 3.8 & 12.4 & 28.6 & 35.9 & 19.0 & 54.9 & 3.67 \\
\hline ASS2 & 3.5 & 10.2 & 20.3 & 42.9 & 23.2 & 66.0 & 3.72 \\
\hline ASS3 & 1.9 & 10.5 & 24.1 & 37.5 & 26.0 & 63.5 & 3.75 \\
\hline ASS4 & 5.1 & 11.4 & 27.6 & 38.7 & 17.1 & 55.9 & 3.51 \\
\hline ASS5 & 5.1 & 10.8 & 31.4 & 36.5 & 16.2 & 52.7 & 3.48 \\
\hline ASS6 & 2.5 & 10.8 & 30.2 & 36.2 & 20.3 & 56.5 & 3.61 \\
\hline Sub-Total & 21.9 & 66.0 & 162.2 & 227.6 & 121.9 & 349.5 & 21.7 \\
\hline Average & 3.7 & 11.0 & 27.0 & 37.9 & 20.3 & 58.3 & 3.6 \\
\hline \multicolumn{8}{|l|}{ SQ4 - Empathy } \\
\hline EMP1 & 5.4 & 11.1 & 27.9 & 33.7 & 21.9 & 55.6 & 3.56 \\
\hline EMP2 & 3.8 & 11.7 & 34.6 & 34.6 & 15.2 & 49.8 & 3.46 \\
\hline EMP3 & 4.8 & 11.4 & 29.5 & 36.8 & 17.5 & 54.3 & 3.51 \\
\hline EMP4 & 3.8 & 8.9 & 30.2 & 36.5 & 20.6 & 57.1 & 3.61 \\
\hline EMP5 & 3.8 & 12.1 & 25.7 & 33.7 & 24.8 & 58.4 & 3.63 \\
\hline EMP6 & 8.3 & 14.0 & 24.1 & 28.9 & 24.8 & 53.7 & 3.48 \\
\hline Sub-Total & 29.8 & 69.2 & 172.1 & 204.1 & 124.8 & 328.9 & 21.2 \\
\hline Average & 5.0 & 11.5 & 28.7 & 34.0 & 20.8 & 54.8 & 3.5 \\
\hline \multicolumn{8}{|c|}{ SQ5 - Tangibility } \\
\hline TAN1 & 4.8 & 12.7 & 32.7 & 33.0 & 16.8 & 49.8 & 3.44 \\
\hline TAN2 & 4.1 & 14.3 & 35.9 & 27.6 & 18.1 & 45.7 & 3.41 \\
\hline TAN3 & 6.3 & 9.8 & 27.0 & 31.4 & 25.4 & 56.8 & 3.60 \\
\hline Sub-Total & 15.2 & 36.8 & 95.6 & 92.1 & 60.3 & 152.4 & 10.5 \\
\hline Average & 5.1 & 12.3 & 31.9 & 30.7 & 20.1 & 50.8 & 3.5 \\
\hline TOTAL & 23.05 & 58.86 & 131.81 & 156.25 & 89.97 & 246.22 & 16.14 \\
\hline AVERAGE & 5.05 & 13.06 & 28.95 & 33.57 & 19.35 & 52.92 & 3.50 \\
\hline
\end{tabular}


Appendix A2. Price

\begin{tabular}{|c|c|c|c|c|c|c|c|}
\hline \multirow{2}{*}{$\begin{array}{c}\text { No } \\
\text { Items }\end{array}$} & \multicolumn{5}{|c|}{ Frequency (\%) } & \multirow[t]{2}{*}{ Total $(4+5)$} & \multirow[t]{2}{*}{ Mean } \\
\hline & 1 & 2 & 3 & 4 & 5 & & \\
\hline \multicolumn{8}{|l|}{ Price (PRI) } \\
\hline PRI1 & 6.3 & 15.2 & 33.7 & 30.8 & 14.0 & 44.8 & 3.31 \\
\hline PRI2 & 3.8 & 12.1 & 37.5 & 30.2 & 16.5 & 46.7 & 3.43 \\
\hline PRI3 & 5.4 & 13.7 & 34.0 & 29.5 & 17.5 & 47.0 & 3.40 \\
\hline PRI4 & 6.3 & 10.5 & 32.1 & 27.9 & 23.2 & 51.1 & 3.51 \\
\hline Sub-Total & 21.90 & 51.43 & 137.14 & 118.41 & 71.11 & 189.52 & 13.65 \\
\hline Average & 5.48 & 12.86 & 34.29 & 29.60 & 17.78 & 47.38 & 3.41 \\
\hline
\end{tabular}

Appendix A3. Customer Satisfaction

\begin{tabular}{|c|c|c|c|c|c|c|c|}
\hline \multirow[t]{2}{*}{ Items } & \multicolumn{5}{|c|}{ Frequency (\%) } & \multirow[t]{2}{*}{ Total $(4+5)$} & \multirow[t]{2}{*}{ Mean } \\
\hline & 1 & 2 & 3 & 4 & 5 & & \\
\hline \multicolumn{8}{|c|}{ CS1 - Expectation } \\
\hline EXP1 & 3.8 & 12.1 & 30.2 & 35.6 & 18.4 & 54.0 & 3.53 \\
\hline EXP2 & 4.4 & 10.2 & 32.4 & 38.4 & 14.6 & 53.0 & 3.49 \\
\hline EXP3 & 3.8 & 12.1 & 31.1 & 34.0 & 19.0 & 53.0 & 3.52 \\
\hline Sub-Total & 12.06 & 34.29 & 93.65 & 107.94 & 52.06 & 160.00 & 10.54 \\
\hline Average & 4.02 & 11.43 & 31.22 & 35.98 & 17.35 & 53.33 & 3.51 \\
\hline \multicolumn{8}{|c|}{ CS2 - Perception } \\
\hline PER1 & 3.2 & 13.0 & 30.2 & 39.4 & 14.3 & 53.7 & 3.49 \\
\hline PER2 & 3.8 & 14.9 & 29.2 & 36.2 & 15.9 & 52.1 & 3.45 \\
\hline PER3 & 1.9 & 11.7 & 31.7 & 34.9 & 19.7 & 54.6 & 3.59 \\
\hline Sub-Total & 8.89 & 39.68 & 91.11 & 110.48 & 49.84 & 160.32 & 10.53 \\
\hline Average & 2.96 & 13.23 & 30.37 & 36.83 & 16.61 & 53.44 & 3.51 \\
\hline \multicolumn{8}{|c|}{ CS3 - Recommendation } \\
\hline REC1 & 5.7 & 7.3 & 28.3 & 34.6 & 24.1 & 58.7 & 3.64 \\
\hline REC2 & 5.1 & 7.0 & 27.3 & 30.5 & 30.2 & 60.6 & 3.74 \\
\hline Sub-Total & 10.79 & 14.29 & 55.56 & 65.08 & 54.29 & 119.37 & 7.38 \\
\hline Average & 5.40 & 7.14 & 27.78 & 32.54 & 27.14 & 59.68 & 3.69 \\
\hline \multicolumn{8}{|c|}{ CS - Overall Satisfaction } \\
\hline TOTAL & 10.58 & 29.42 & 80.11 & 94.50 & 52.06 & 146.56 & 9.48 \\
\hline$A V E R A G E$ & 4.13 & 10.60 & 29.79 & 35.11 & 20.37 & 55.49 & 3.57 \\
\hline
\end{tabular}


Vol. 3, Issue 2, pp. 1-16, 2021

Available online at: https://tljbm.org/jurnal/index.php/tljbm

Appendix A4. WOM

\begin{tabular}{|c|c|c|c|c|c|c|c|}
\hline \multirow[t]{2}{*}{ No Item } & \multicolumn{5}{|c|}{ Frequency $(\%)$} & \multirow[t]{2}{*}{ Total $(4+5)$} & \multirow[t]{2}{*}{ Mean } \\
\hline & 1 & 2 & 3 & 4 & 5 & & \\
\hline \multicolumn{8}{|c|}{ WOM1 - Information (INF) } \\
\hline INF1 & 6.0 & 10.2 & 27.6 & 34.6 & 21.6 & 56.2 & 3.56 \\
\hline INF2 & 3.2 & 9.2 & 26.0 & 31.4 & 30.2 & 61.6 & 3.76 \\
\hline INF3 & 4.1 & 11.1 & 30.5 & 31.4 & 22.9 & 54.3 & 3.58 \\
\hline Sub-Total & 13.33 & 30.48 & 84.13 & 97.46 & 74.60 & 172.06 & 10.90 \\
\hline Average & 4.44 & 10.16 & 28.04 & 32.49 & 24.87 & $\mathbf{5 7 . 3 5}$ & 3.63 \\
\hline \multicolumn{8}{|c|}{ WOM2 - Promotion (PRO) } \\
\hline PRO1 & 4.8 & 9.2 & 27.0 & 39.0 & 20.0 & 59.0 & 3.60 \\
\hline PRO2 & 2.2 & 12.4 & 28.9 & 36.8 & 19.7 & 56.5 & 3.59 \\
\hline PRO3 & 5.4 & 10.2 & 27.9 & 37.5 & 19.0 & 56.5 & 3.55 \\
\hline Sub-Total & 12.38 & 31.75 & 83.81 & 113.33 & 58.73 & 172.06 & 10.74 \\
\hline Average & 4.13 & 10.58 & 27.94 & 37.78 & 19.58 & 57.35 & 3.58 \\
\hline \multicolumn{8}{|c|}{ WOM3 - Retention ( RET) } \\
\hline RET1 & 5.7 & 3.8 & 24.4 & 33.3 & 32.7 & 66.0 & 3.83 \\
\hline Sub-Total & 5.71 & 3.81 & 24.44 & 33.33 & 32.70 & 66.03 & 3.83 \\
\hline Average & 5.71 & 3.81 & 24.44 & 33.33 & 32.70 & 66.03 & 3.83 \\
\hline TOTAL & 10.48 & 22.01 & 64.13 & 81.38 & 55.34 & 136.72 & 8.49 \\
\hline AVERAGE & 4.76 & 8.18 & 26.81 & 34.53 & 25.71 & 60.25 & 3.68 \\
\hline
\end{tabular}

